\title{
Atmospheric mercury and fine particulate matter in coastal New England: Implications for mercury and trace element sources in the northeastern United States
}

\author{
Allan Kolker a,*, Mark A. Engle ${ }^{\mathrm{a}, 1}$, Bernhard Peucker-Ehrenbrink ${ }^{\mathrm{b}}$, Nicholas J. Geboy ${ }^{\mathrm{a}}$, \\ David P. Krabbenhoft ${ }^{c}$, Michael H. Bothner ${ }^{\mathrm{d}}$, Michael T. Tate ${ }^{\mathrm{c}}$ \\ ${ }^{a}$ U.S. Geological Survey, Eastern Energy Resources Science Center, Reston, VA 20192, USA \\ ${ }^{\mathrm{b}}$ Woods Hole Oceanographic Institution, Dept. of Marine Chemistry E Geochemistry, Woods Hole, MA, USA \\ ${ }^{\mathrm{c}}$ U.S. Geological Survey, Wisconsin Water Science Center, Middleton, WI, USA \\ ${ }^{\mathrm{d}}$ U.S. Geological Survey, Woods Hole Science Center, Woods Hole, MA, USA
}

\section{H I G H L I G H T S}

- Contribution of natural and anthropogenic $\mathrm{PM}_{2.5}$ sources is quantified.

- Back-trajectories for marine and crustal sources each show input from offshore.

- Results for crustal source are explained by long-range transport of Saharan dust.

- Results for $\mathrm{Hg}$ species, $\mathrm{SO}_{2}$ and $\mathrm{NO}_{x}$ show influence of combustion-related plumes

- Results for RGM show diurnal cycle of production characteristic of marine influence.

\section{A R T I C L E I N F O}

\section{Article history:}

Received 1 March 2013

Received in revised form

27 June 2013

Accepted 15 July 2013

\section{Keywords:}

Trace elements

$\mathrm{PM}_{2.5}$

Mercury speciation

Source attribution

Saharan dust

Transport of pollutants

Woods Hole

Cape Cod

Massachusetts

Coastal New England

\begin{abstract}
A B S T R A C T
Intensive sampling of ambient atmospheric fine particulate matter was conducted at Woods Hole, Massachusetts over a four-month period from 3 April to 29 July, 2008, in conjunction with year-long deployment of the USGS Mobile Mercury Lab. Results were obtained for trace elements in fine particulate matter concurrently with determination of ambient atmospheric mercury speciation and concentrations of ancillary gasses $\left(\mathrm{SO}_{2}, \mathrm{NO}_{x}\right.$, and $\left.\mathrm{O}_{3}\right)$. For particulate matter, trace element enrichment factors greater than 10 relative to crustal background values were found for $\mathrm{As}, \mathrm{Bi}, \mathrm{Cd}, \mathrm{Cu}, \mathrm{Hg}, \mathrm{Pb}, \mathrm{Sb}, \mathrm{V}$, and $\mathrm{Zn}$, indicating contribution of these elements by anthropogenic sources. For other elements, enrichments are consistent with natural marine $(\mathrm{Na}, \mathrm{Ca}, \mathrm{Mg}, \mathrm{Sr}$ ) or crustal $\mathrm{Ba}, \mathrm{Ce}, \mathrm{Co}, \mathrm{Cs}, \mathrm{Fe}, \mathrm{Ga}, \mathrm{La}, \mathrm{Rb}, \mathrm{Sc}$, Th, Ti, U, Y) sources, respectively. Positive matrix factorization was used together with concentration weighted air-mass back trajectories to better define element sources and their locations. Our analysis, based on events exhibiting the $10 \%$ highest $\mathrm{PM}_{2.5}$ contributions for each source category, identifies coalfired power stations concentrated in the U.S. Ohio Valley, metal smelting in eastern Canada, and marine and crustal sources showing surprisingly similar back trajectories, at times each sampling Atlantic coastal airsheds. This pattern is consistent with contribution of Saharan dust by a summer maximum at the latitude of Florida and northward transport up the Atlantic Coast by clockwise circulation of the summer Bermuda High. Results for mercury speciation show diurnal production of RGM by photochemical oxidation of $\mathrm{Hg}^{\circ}$ in a marine environment, and periodic traverse of the study area by correlated RGM$\mathrm{SO}_{2}\left(\mathrm{NO}_{x}\right)$ plumes, indicative of coal combustion sources.
\end{abstract}

Published by Elsevier Ltd.

\footnotetext{
* Corresponding author.

E-mail address: akolker@usgs.gov (A. Kolker).

1 Present address: U.S. Geological Survey, University of Texas at El Paso, El Paso, TX 79968, USA.
}

\section{Introduction}

Proximity of urbanized areas to coastal ecosystems provides a ready source for atmospheric transport of mercury $(\mathrm{Hg})$ and other contaminants. Where element enrichments in atmospheric aerosols greatly exceed proportions expected in natural crustal or 
marine background inputs, anthropogenic sources are indicated (Duce et al., 1975; Pacyna and Pacyna, 2001; Song et al., 2001). In the absence of anthropogenic inputs, coastal areas are primarily influenced by marine aerosols enriched in constituents that are concentrated in seawater, such as $\mathrm{Na}, \mathrm{Mg}$, and $\mathrm{Sr}$, and terrigenous aerosols characterized by lithophile elements that are enriched in the Earth's crust, such as $\mathrm{Al}, \mathrm{Zr}$ and the rare earth elements (REE).

In the present study, we collected a nearly four month (03 April to 29 July, 2008) sequence of atmospheric fine particulate matter $\left(\mathrm{PM}_{2.5}\right)$ at a coastal site on the Quissett Campus of Woods Hole Oceanographic Institution (WHOI), at the southwestern extent of Cape Cod, Massachusetts, USA (Fig. 1). We use positive matrix factorization (PMF), a data analysis approach, together with concentration weighted trajectory analysis (CWT), an air-mass trajectory approach, to understand the sources controlling $\mathrm{PM}_{2.5}$ chemistry and their geographic distribution. The study area is residential to rural, with no large emission sources within $50 \mathrm{~km}$ of the site (2008 $\mathrm{Hg}$ emissions only $6.4 \mathrm{~kg} \mathrm{yr}^{-1}$ ), and none within $10 \mathrm{~km}$ (Engle et al., 2010a). However, the area is located within $100 \mathrm{~km}$ of the urban centers of Boston, Massachusetts and Providence, Rhode Island, and within about $275 \mathrm{~km}$ of the New York City metropolitan area (Fig. 1). The proximity of these northeastern urban centers influences air quality on Cape Cod, including ozone levels, especially during the summer months (Massachusetts Department of the Environment, 2012; U.S. EPA, 2012b; Cooper et al., 2012).

Previous sampling for $\mathrm{PM}_{2.5}$ chemistry at coastal sites in the eastern U.S. includes the New York-New Jersey Harbor estuary (Gao et al., 2002), and Brigantine, New Jersey, along the southern New Jersey coast (Song et al., 2001) together with two inland sites. These studies identify source categories including fossil energy, marine, soil/crustal, and metal smelting, as well as waste incineration, whose impact has been reduced by subsequent EPA regulations. Golomb et al. (1997) compared trace element concentrations in wet and dry deposition over a one-year interval at Nahant, Massachusetts, near Boston, with that at Truro, a more rural site near the northern extent of Cape Cod. These authors found that although metal concentrations in dry deposition were generally higher at Nahant, annual wet deposition for elements such as Se, $\mathrm{Co}, \mathrm{Sb}, \mathrm{Zn}, \mathrm{Pb}$, etc. was higher at Truro. Golomb et al. considered this to be due to rainout of metals from air masses that had traversed the urban corridor to the southwest that includes New York City.

For $\mathrm{Hg}$ speciation, recent work provides multiyear data for two sites in southern New Hampshire that should be comparable to the WHOI site. These include a coastal site at Thompson Farm, and an offshore site at Appledore Island (Mao and Talbot, 2012; Mao et al., 2012; Sigler et al., 2009a,b). These studies show differences in $\mathrm{Hg}$ speciation between the two coastal/offshore sites and an upland site inland. The two marine-influenced sites show a diurnal cycle of reactive gaseous mercury (RGM) production characteristic of sites having a marine influence (Laurier and Mason, 2007; Engle et al., 2008).

The present study is one of a series of coastal studies conducted by the U.S. Geological Survey between 2005 and 2010, aimed at understanding controls on atmospheric $\mathrm{Hg}$ deposition in coastal environments (Kolker et al., 2007; Engle et al., 2008, 2010a), and ultimately, $\mathrm{Hg}$ uptake and availability in coastal ecosystems (Engle et al., 2010b, Geboy et al., 2011; Fig. 1). A summary of seasonal variation in $\mathrm{Hg}$ speciation at the WHOI site is given by Engle et al. (2010a), in comparison with eight other sites in central and eastern North America. Among coastal sites studied by the USGS, the WHOI site is the first of two more northerly sites (Acadia National Park, Maine is the other), sampled to determine the effect of climate on $\mathrm{Hg}$ speciation, in comparison with warmer water coastal sites at Weeks Bay National Estuarine Reserve, Alabama, Cape Romain, South Carolina, and Luquillo National Forest, Puerto Rico (Engle et al., 2008, 2010a).

\section{Methods}

\subsection{Sampling protocols}

Atmospheric aerosol samplers were deployed above tree-top level on a permanent observation tower with open exposure to the ocean less than $200 \mathrm{~m}$ from the shore. The bulk of this study is

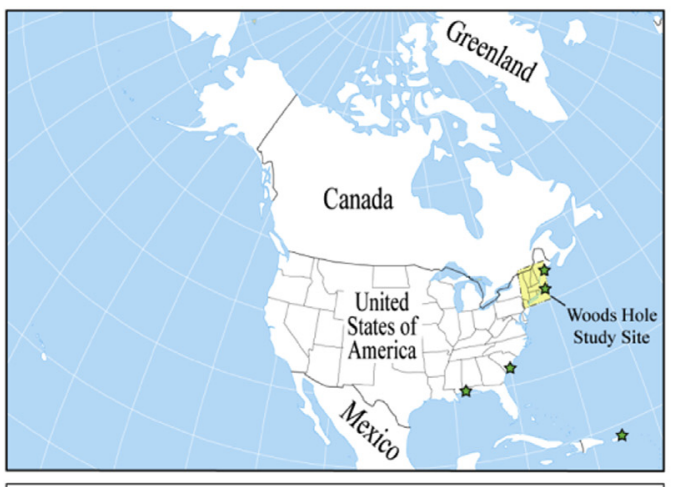

Legend:

Coastal mercury study site

Atmospheric Mercury Emission Sources

$$
\begin{array}{ll}
\text { - } 0-8.7 \mathrm{~kg} / \mathrm{yr} & \text { ○ } 51.9-82.5 \mathrm{~kg} / \mathrm{yr} \\
\text { - } 8.8-26.8 \mathrm{~kg} / \mathrm{yr} & \bigcirc 82.6-183 \mathrm{~kg} / \mathrm{yr} \\
\text { - } 26.9-51.8 \mathrm{~kg} / \mathrm{yr} &
\end{array}
$$

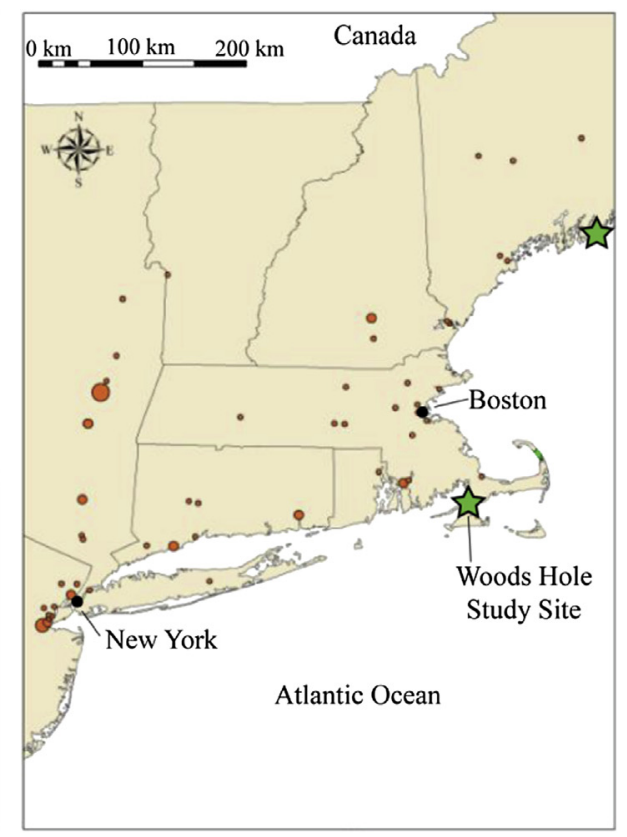

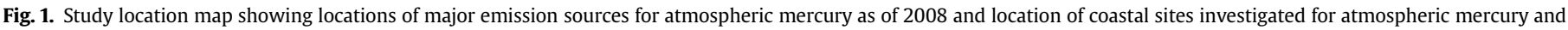

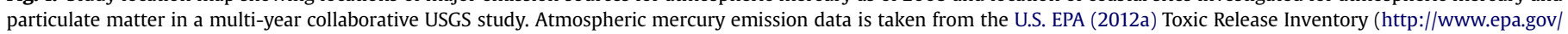
triexplorer/). 
PM 2.5 Data from Cape Cod, Apr-July 2008

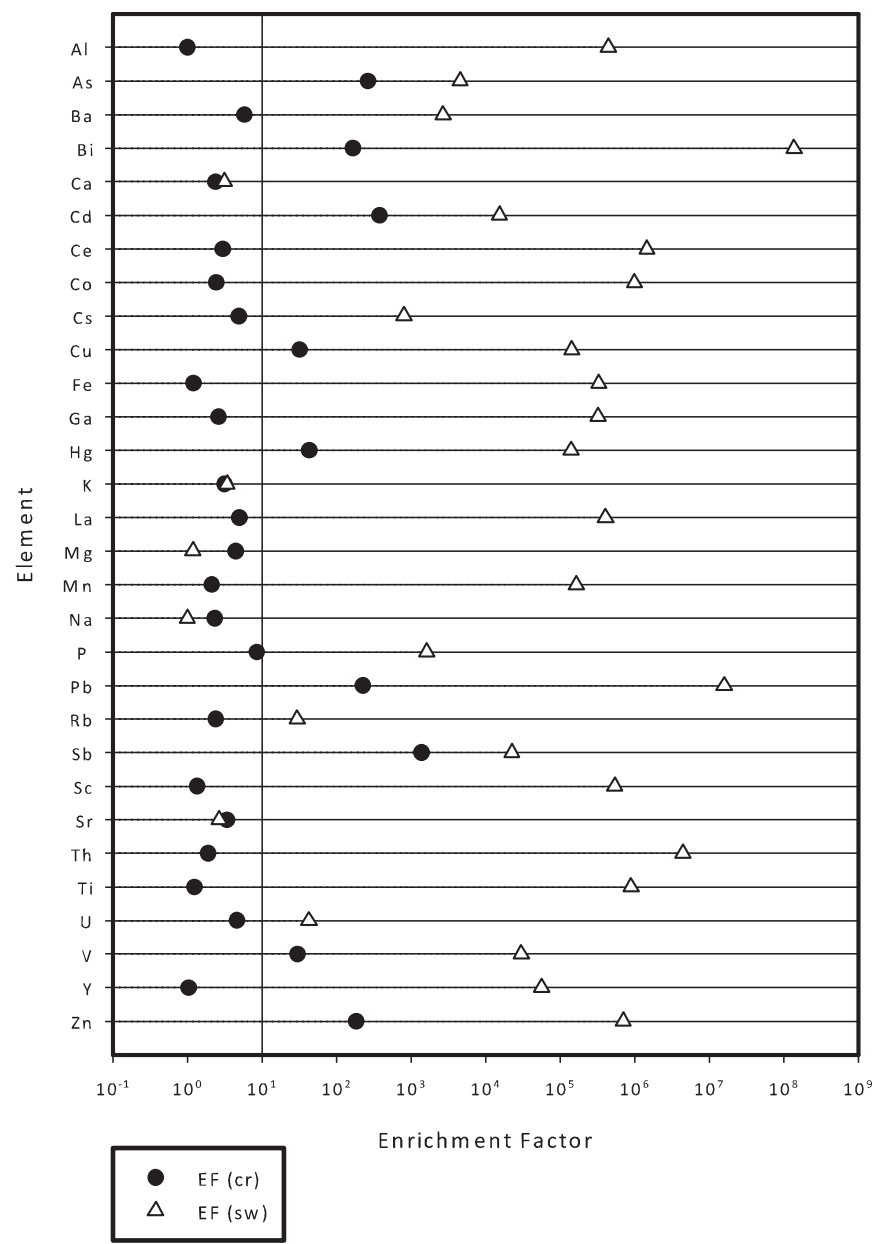

Fig. 2. $\mathrm{PM}_{2.5}$ element enrichment factors (EFs) vs. crustal ( $\mathrm{cr}-$ solid circles) and marine (sw - open triangles) sources represented by $\mathrm{Al}$ and $\mathrm{Na}$, respectively, which are defined by EF's of 1.0 for each source. Elements having enrichment factors of 10 or more relative to both natural sources include $\mathrm{As}, \mathrm{Bi}, \mathrm{Cd}, \mathrm{Cu}, \mathrm{Hg}, \mathrm{Pb}, \mathrm{Sb}, \mathrm{V}$, and $\mathrm{Zn}$. Based on their EFs, these elements are likely contributed by anthropogenic sources.

based on $73 \mathrm{PM}_{2.5}$ samples taken in 1-6 day intervals from 03 April to 29 July, 2008. This sampling was conducted using two tripodmounted low volume samplers in which $\mathrm{PM}_{2.5}$ were collected on acid-cleaned $47 \mathrm{~mm}$ PTFE filters for trace metals (TM). In addition to the above, $\mathrm{PM}$, including $\mathrm{PM}_{2.5}$, coarse particulate $\left(\mathrm{PM}_{10}\right)$, and total suspended particulate (TSP) samples were collected in 12 h day/12-h night intervals from 21 to 28 February, and from 29 July to 4 August, 2008, using tripod-mounted low-volume (16.7- or $42 \mathrm{~L} \mathrm{~min}^{-1}$ ) pump/filter pack assemblies.

The USGS Mobile Mercury Lab (Mobile Lab) was deployed on the WHOI Quissett Campus from 1 February, 2008 until 6 January, 2009, coincident with PM sampling described above. For mercury speciation, the Mobile Lab is equipped with a Tekran 1130/1135 Hg speciation unit coupled to a Tekran 2537A Cold Vapor Atomic Fluorescence Spectrometer (CVAFS). Our standard sampling and $\mathrm{QA} / \mathrm{QC}$ protocols for measurement of atmospheric $\mathrm{Hg}$ species in coastal environments were followed (see Engle et al., 2008, 2010a; Kolker et al., 2008, 2010). Briefly, the mercury speciation system operates on a repeating $2 \mathrm{~h}$ cycle, sequentially collecting reactive gaseous mercury (RGM) on a $\mathrm{KCl}$-coated annual denuder, fine particulate mercury $\left(\mathrm{Hg}-\mathrm{PM}_{2.5}\right)$ on a regenerable particulate filter, and gaseous elemental mercury $\left(\mathrm{Hg}^{\circ}\right)$ on gold traps. Each fraction of mercury collected is thermally desorbed and analyzed by the Tekran 2537 $\mathrm{A}$ as $\mathrm{Hg}^{\circ}$. System blanks were calculated as the average $\mathrm{Hg}$ concentrations for the two intervals immediately prior to and after determination of the $\mathrm{Hg}-\mathrm{PM}_{2.5}$ and RGM species for each $2 \mathrm{~h}$ interval and subtracted from the $\mathrm{Hg}$ concentrations for that interval. Detection limits for ambient $\mathrm{Hg}^{\circ}\left(0.1 \mathrm{ng} \mathrm{m}^{-3}\right)$ are well below the range of observed values for $\mathrm{Hg}^{\circ}$ in this study. Detection limits for RGM and $\mathrm{Hg}-\mathrm{PM}_{2.5}$ are not precisely known, but a value of $2.0 \mathrm{pg} \mathrm{m}^{-3}$ is used in this study as a cut-off below which RGM and $\mathrm{Hg}-\mathrm{PM}_{2.5}$ values are not reported. Using this lower limit, approximately $62 \%$ of RGM and $81 \%$ of $\mathrm{Hg}-\mathrm{PM}_{2.5}$ values obtained are below the detection limit. The CVAFS was calibrated every 1-7 days using an internal permeation source which was checked against manual $\mathrm{Hg}^{\circ}$ injections every $1-2$ months. Replacement intervals for annual denuders were every $2-4$ weeks and the regenerating particulate filter was replaced every 1-2 months, or sooner if needed. Bias checks for the two gold traps showed average differences of less than $5 \%$. In addition to speciated mercury, the Mobile Lab is equipped with samplers/analyzers for $\mathrm{PM}_{2.5}$ mass (TEOM), as well as ancillary gasses including $\mathrm{O}_{3}, \mathrm{NO}_{x}$ and $\mathrm{SO}_{2}$ (Thermo-Environmental Models 49C, 43C, and 42C, respectively), and recording meteorological data, including temperature, barometric pressure, wind speed and direction, incident solar radiation, and leaf wetness, each collected in intervals of $5 \mathrm{~min}$ on a Campbell Scientific data logger.

\subsection{Analytical methods}

Particulate samples for trace metal analysis were extracted from filter media using a 4-acid digestion method and analyzed by ICPMS for a suite of approximately 30 elements (Briggs and Meier,

Table 1

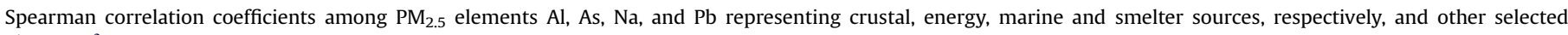
elements. ${ }^{\mathrm{a}}$

\begin{tabular}{|c|c|c|c|c|c|c|c|c|c|c|c|c|}
\hline & $\mathrm{Al}$ & As & $\mathrm{Na}$ & $\mathrm{Pb}$ & $\mathrm{Cd}$ & $\mathrm{Ce}$ & Cs & $\mathrm{Fe}$ & Ga & $\mathrm{Mg}$ & $\mathrm{Ti}$ & $\mathrm{V}$ \\
\hline $\mathrm{Al}$ & & 0.14 & 0.21 & 0.23 & 0.26 & 0.84 & 0.76 & 0.79 & 0.87 & 0.40 & 0.76 & 0.27 \\
\hline As & & & 0.00 & 0.63 & 0.72 & 0.44 & 0.38 & 0.48 & 0.36 & 0.03 & 0.45 & 0.63 \\
\hline $\mathrm{Na}$ & & & & -0.24 & -0.09 & 0.16 & 0.17 & 0.12 & 0.21 & 0.95 & 0.21 & 0.24 \\
\hline $\mathrm{Pb}$ & & & & & 0.88 & 0.38 & 0.43 & 0.43 & 0.43 & -0.14 & 0.26 & 0.28 \\
\hline $\mathrm{Cd}$ & & & & & & 0.45 & 0.54 & 0.50 & 0.52 & 0.00 & 0.39 & 0.42 \\
\hline $\mathrm{Ce}$ & & & & & & & 0.81 & 0.95 & 0.84 & 0.32 & 0.89 & 0.53 \\
\hline Cs & & & & & & & & 0.82 & 0.82 & 0.34 & 0.76 & 0.30 \\
\hline $\mathrm{Fe}$ & & & & & & & & & 0.85 & 0.24 & 0.91 & 0.56 \\
\hline $\mathrm{Ga}$ & & & & & & & & & & 0.39 & 0.76 & 0.47 \\
\hline $\mathrm{Mg}$ & & & & & & & & & & & 0.35 & 0.24 \\
\hline $\mathrm{Ti}$ & & & & & & & & & & & & 0.53 \\
\hline $\mathrm{V}$ & & & & & & & & & & & & \\
\hline
\end{tabular}

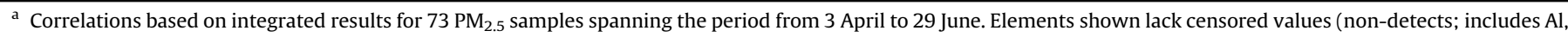
$\mathrm{Na}, \mathrm{Pb}, \mathrm{Ce}, \mathrm{Cs}, \mathrm{Ga}, \mathrm{Mg}, \mathrm{V}$ ) or have a minimum of censored values (As, Cd, Fe, Ti). Analysis detection limits are substituted for censored values in calculations. 
2002), at USGS Central Mineral and Environmental Resources Science Center laboratories in Denver, Colorado. Recovery of trace elements from triplicate analysis of a particulate matter reference material (NIST SRM 1648a) and quadruplicate analysis of a soil standard (NIST SRM 2709a) was within $20 \%$ of reported values for all elements examined here. A total of 13 field blanks were collected over the course of the investigation and analyzed for trace elements; all data were blank corrected and method detection limits were calculated as three times the standard deviation of the field blanks. Concentrations of $\mathrm{Al}, \mathrm{Cd}, \mathrm{Mg}, \mathrm{Na}, \mathrm{Sr}$, and $\mathrm{V}$ in these samples exceed detection limits in nearly all cases, whereas As, Ba, Ce, Ga,
$\mathrm{La}, \mathrm{Rb}, \mathrm{Sb}, \mathrm{Y}$, and $\mathrm{Zn}$, are quantifiable in approximately half of the samples. A greater number of elements are measureable in the TSP samples and in $\mathrm{PM}_{2.5}$ samples collected over $24 \mathrm{~h}$ or more. Six sets of duplicate filters, collected within a $2 \mathrm{~m}$ distance, showed less than $30 \%$ median difference between pairs for all elements except for Y (31\%) and Ga (37\%).

\subsection{Data analysis approaches}

In order to distinguish possible source categories contributing to $\mathrm{PM}_{2.5}$ at the Cape Cod site, element enrichment factors (EFs) were

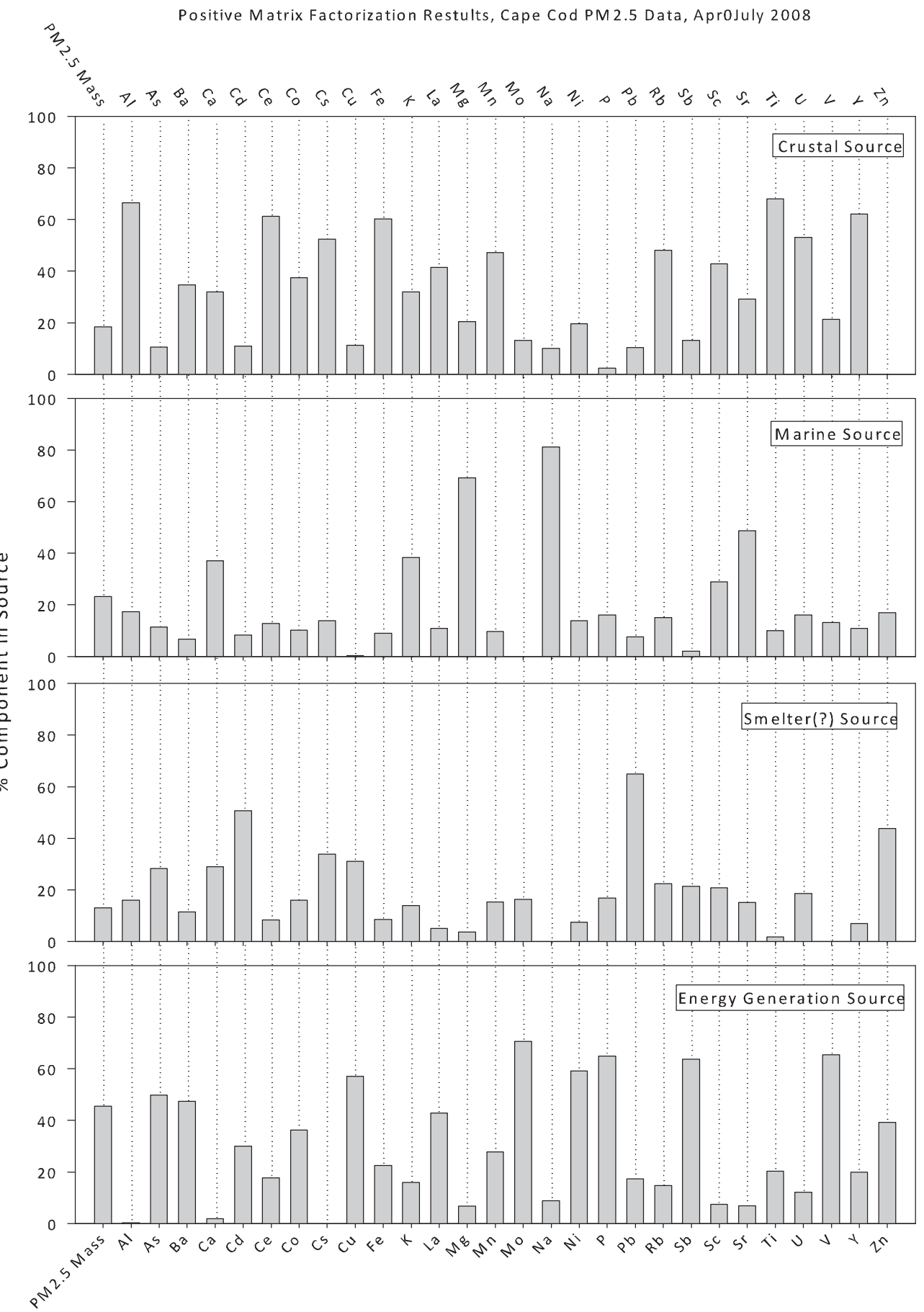

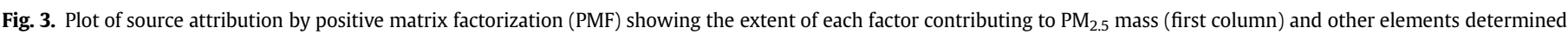
for the period of continuous $\mathrm{PM}_{2.5}$ sampling, 3 April to 29 July, 2008. 
calculated in relation to natural sources represented by Al for a crustal source and Na for a marine source, (Duce et al., 1975):

$$
\begin{aligned}
\mathrm{EF}_{(\mathrm{El})=} & \operatorname{conc}(\mathrm{El})_{\text {sample }} / \operatorname{conc}(\mathrm{Al} \text { or } \mathrm{Na})_{\text {sample }} / \\
& \operatorname{conc}(\mathrm{El})_{\text {crust or seawater }} / \operatorname{conc}(\mathrm{Al}) \text { crust or } \operatorname{conc}(\mathrm{Na})_{\text {seawater }}
\end{aligned}
$$

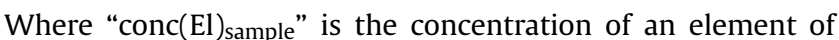
interest in a sample and "conc(El) crust or seawater" is the concentration of that element in the Earth's crust or in seawater. In this analysis, elements with enrichment factors of 10 or more relative to natural sources are considered to be derived from anthropogenic sources (Duce et al., 1975).

In order to gain a more detailed understanding of potential $\mathrm{PM}_{2.5}$ sources, trace element data were subjected to positive matrix factorization (PMF) analysis using the EPA PMF 3.0 model (U.S. EPA, 2012c). In general, data reduction techniques such as PMF, factor analysis, and similar approaches, are mathematical methods to group observed variables (i.e., trace elements) into a fewer number of unobserved variables called factors or components (i.e., emission sources of the trace elements). For purposes of source apportionment, the factors are then regressed against a species of interest, such as $\mathrm{PM}_{2.5}$ mass. For environmental data, it has been shown that PMF is better suited than customary factor- or principal component analysis since it guarantees non-negative results (Paatero and Tapper, 1994), particularly for receptor modeling (Reff et al., 2007 and references therein), and can accept varied levels of uncertainty for each measurement and parameter.

To determine concentration-weighted back trajectories for each of the source factors identified by PMF, air-mass back trajectories from the study area were first calculated using data from the U.S. National Oceanic and Atmospheric Administration's (NOAA) Eta Data Assimilation System (EDAS) archive. These trajectories were combined with results from the PMF analysis in the GIS-based software program, TrajStat (Wang et al., 2009), a program that uses trajectory statistical analysis data to identify potential source locations from long-term air pollution measurements. To produce a visualization of concentration-weighted back trajectories, modeled $\mathrm{PM}_{2.5}$ contributions for each source from the PMF model were used as the input data for TrajStat, resulting in four sets of analyses (one for each source). As such, the modeling results highlight the areas of largest mass contribution towards $\mathrm{PM}_{2.5}$ from the different sources. The model was constrained using a grid size of $1 / 2$ degree by $1 / 2$ degree with back air mass trajectories calculated every six hours for

Mercury Species, Cape Cod, Apr-July 2008
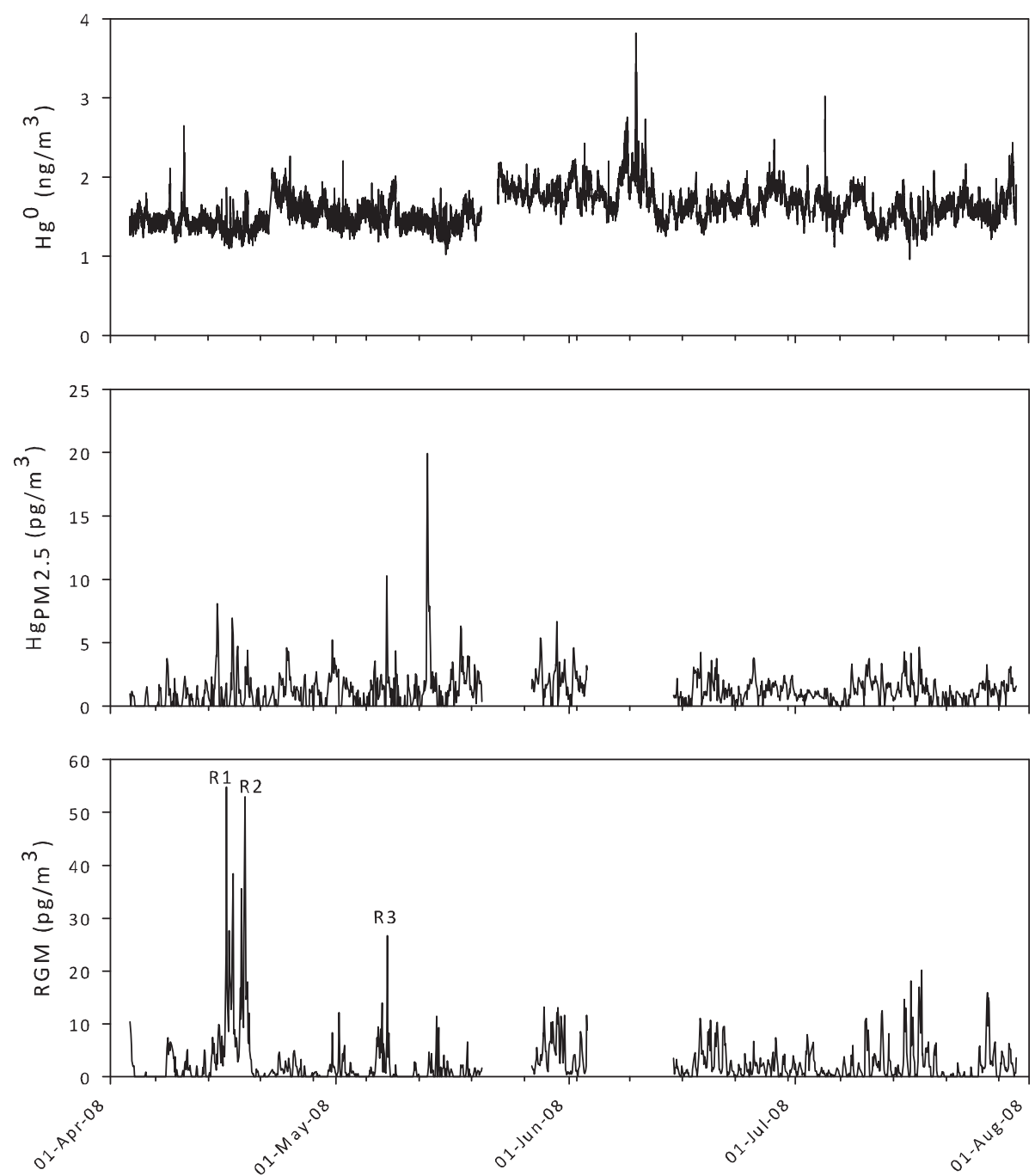

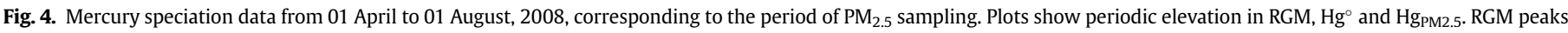
$\mathrm{R} 1, \mathrm{R} 2$ and R3 are discussed in text. Plot also shows smaller variation in RGM on a diurnal time scale. 
$72 \mathrm{~h}$ at a starting height of $6 \mathrm{~m}$ (equal to the elevation of the inlets for the $\mathrm{PM}_{2.5}$ samplers).

\section{Results}

\subsection{Element enrichment factors}

Calculation of cumulative enrichment factors for the 4-month PM sampling period (Fig. 2) distinguishes three groups of elements - a group that is enriched by a factor of 10 or more in relation to both $\mathrm{Na}$ and $\mathrm{Al}$, indicating these are derived from one or more anthropogenic sources (includes $\mathrm{As}, \mathrm{Bi}, \mathrm{Cd}, \mathrm{Cu}, \mathrm{Hg}, \mathrm{Pb}, \mathrm{Sb}, \mathrm{V}$, $\mathrm{Zn}$ ); a second group that shows no enrichment in relation to $\mathrm{Al}$, indicating a crustal source (includes $\mathrm{Ba}, \mathrm{Ce}, \mathrm{Co}, \mathrm{Cs}, \mathrm{Fe}, \mathrm{Ga}, \mathrm{La}, \mathrm{Rb}, \mathrm{Sc}$, $\mathrm{Th}, \mathrm{Ti}, \mathrm{U}, \mathrm{Y}$ ); and a third group showing no enrichment relative to $\mathrm{Na}$, indicating a marine source (includes $\mathrm{Ca}, \mathrm{Mg}$, Sr; Fig. 2).

\subsection{Source attribution of trace elements}

Using the EPA PMF 3.0 model, the best model fit created four factors characterized by the following components: 1) Al, Ti, Y, Fe, $\mathrm{Rb}, \mathrm{Ce}, \mathrm{Cs}, \mathrm{Sc}$, La, and U; 2) Na, Mg, Sr, K and Ca; 3) Pb, Cd and Zn; and 4) As, Mo, $\mathrm{V}, \mathrm{Sb}, \mathrm{Ni}$ and $\mathrm{Cu}$. These factors are interpreted to represent crustal, marine, a potential smelter source, and energy generation sources, respectively (Fig. 4). Trace metals with over $80 \%$ of the data censored (including $\mathrm{Hg}$ ), were omitted from the model, whereas those with $50-80 \%$ of the data censored were rated "low impact". Inter-element correlations using $\mathrm{Al}, \mathrm{Na}, \mathrm{Pb}$, and $\mathrm{As}$ to represent the four respective model factors, are consistent with element groupings identified using PMF (Table 1). PMF results largely mimic sources identified using robust factor analysis on the same dataset (Engle et al., 2011) and those inferred from previous work at sites along the northeastern U.S. Atlantic Coast (Song et al., 2001; Gao et al., 2002; Sigler et al., 2009a,b). In addition to identifying dominant factors contributing to $\mathrm{PM}_{2.5}$, the model also estimates the proportion of the $\mathrm{PM}_{2.5}$ mass that can be attributed to input from each of the four sources over the study period. The energy generation source is the dominant contributor to $\mathrm{PM}_{2.5}$ at the WHOI site, accounting for $45.5 \%$ of the mass determined. The marine (23.1\%), crustal (18.4\%), and smelter (13.0\%) sources account for the remainder of $\mathrm{PM}_{2.5}$ mass over the four month study period (Fig. 3).

\subsection{Mercury speciation}

Mercury speciation data for the 4-month interval of detailed $\mathrm{PM}_{2.5}$ sampling are shown in Fig. 4. For $\mathrm{Hg}^{\circ}$, baseline concentrations scatter about a value of $1.5 \mathrm{ng} \mathrm{m}^{-3}$, within the range found by Engle et al. (2010a) for rural and coastal sites not impacted by local emission sources, and typical of background $\mathrm{Hg}^{\circ}$ concentrations in North America (1.3-1.8 ng m${ }^{-3}$; Valente et al., 2007). Changes in baseline elevation for $\mathrm{Hg}^{\circ}$ over the course of sampling correspond to periods of instrument recalibration (Fig. 4). For RGM, 2-h concentrations exceeding 10 times the nominal baseline value of $2 \mathrm{pg} \mathrm{m}^{-3}$ occurred one or more times on 5 days during the period of $\mathrm{PM}_{2.5}$ sampling and an additional 8 days overall. The largest RGM peaks occurred on 11 February (max. $53.57 \mathrm{pg} \mathrm{m}^{-3}$ ); 16 April (R1, max. $54.8 \mathrm{pg} \mathrm{m}^{-3}$ ), and 18 April (R2; max. $53.0 \mathrm{pg} \mathrm{m}^{-3}$; Fig. 4). These events commonly show elevation in both $\mathrm{SO}_{2}$ and $\mathrm{NO}_{x}$ within minutes or hours of the RGM peak arrival (e.g. 11 February; 16 April; Table 2). In some cases, however, there is no corresponding $\mathrm{SO}_{2}$ peak and only $\mathrm{NO}_{x}$ is elevated (e.g. 17 April), and on other occasions, $\mathrm{SO}_{2}$ concentrations show only a broadly elevated baseline corresponding to the arrival of the RGM maximum, together with elevation of $\mathrm{NO}_{x}$ (e.g. 7 May, peak R3; Fig. 4; Table 2). Some RGM peaks show corresponding $\mathrm{HgPM}_{2.5}$ maxima (11 February; 24 March; 7 May; Table 2; Fig. 4), consistent with partitioning of oxidized mercury between the gas and the solid phases (Amos et al., 2012).

\subsection{Ancillary gas data}

Results for ancillary gases $\left(\mathrm{NO}_{x}, \mathrm{SO}_{2}, \mathrm{O}_{3}\right)$ obtained in conjunction with trace element and mercury speciation data are shown in Fig. 5. As noted above, in many cases, $\mathrm{SO}_{2}$ maxima correspond with $\mathrm{RGM}$ peaks, indicating that these are derived from coal combustion sources. Examples include 16 April (max. $36.2 \mathrm{ppb} \mathrm{SO}_{2}$ at 9:25 corresponding to $54.8 \mathrm{pg} \mathrm{m}^{-3} \mathrm{RGM}$ at 10:35; S1); 1 May (max. $24.6 \mathrm{ppb} \mathrm{SO}_{2}$ at 10:10 corresponding to $12.2 \mathrm{pg} \mathrm{m}^{-3} \mathrm{RGM}$ at 9:35; S2), 6 May (max. $16.9 \mathrm{ppb} \mathrm{SO}_{2}$ at 13:40 corresponding to $9.5 \mathrm{pg} \mathrm{m}^{-3}$ RGM at 13:35; S3) and 7 May (max. $13.3 \mathrm{ppb} \mathrm{SO}_{2}$ at $1: 35$ corresponding to $14.0 \mathrm{pg} \mathrm{m}^{-3} \mathrm{RGM}$ at $1: 35$; $\mathrm{S} 4$; Fig. 5). In other cases, for example, on 24 June (30.3 ppb $\mathrm{SO}_{2}$ at 8:10; S5), short lived $\mathrm{SO}_{2}$ maxima appear to occur independently of pronounced $\mathrm{NO}_{x}$ and RGM elevation (Fig. 5). $\mathrm{NO}_{\mathrm{x}}$ shows periodic elevation exceeding $50 \mathrm{ppb}$ on at least 10 occasions during the PM study interval between 03 April and 29 July, 2008 (Fig. 6). In some cases, for example on 23 April, short-lived $\mathrm{NO}_{\mathrm{x}}$ plumes (71.5-84.45 ppb from 7:40 to 8:00) appear to be independent of other parameters. In other cases, $\mathrm{NO}_{x}$ and $\mathrm{SO}_{2}$ show more extended elevation at lower levels over multiple hours.

\subsection{Air mass back trajectories with source apportionment}

TrajStat provides a useful visualization of probable source areas for the four source factors identified by PMF. CWT back trajectories shown in Fig. 6 represent the highest 10\% contribution periods for each factor for an air mass originating from a given cell. Air masses containing the components of the smelter-sourced factor $(\mathrm{Pb}, \mathrm{Cd}$ and $\mathrm{Zn}$ ) largely originate from northern Ontario, Canada, an area with active metal extraction and refining (Fig. 6a). The factor interpreted to represent energy generation ( $\mathrm{As}, \mathrm{Bi}, \mathrm{Cd}, \mathrm{Cu}, \mathrm{Hg}, \mathrm{Ni}$,

Table 2

Comparison of $\mathrm{Hg}$ species and hourly ancillary gas data for selected dates having 2-h $\mathrm{RGM} \geq 20 \mathrm{pg} \mathrm{m}^{-3 a} \mathrm{RGM}$ peaks and elevated values for corresponding species are highlighted.

\begin{tabular}{lrrrlccl}
\hline \multirow{2}{*}{2008 Date } & $\begin{array}{c}\text { Local } \\
\text { time }\end{array}$ & $\begin{array}{c}\mathrm{RGM} \\
\left(\mathrm{pg} \mathrm{m}^{-3}\right)\end{array}$ & $\begin{array}{l}\mathrm{HgPM}_{2.5} \\
\left(\mathrm{pg} \mathrm{m}^{-3}\right)\end{array}$ & $\begin{array}{l}\mathrm{Hg}^{\circ} \\
\left(\mathrm{ng} \mathrm{m}^{-3}\right)\end{array}$ & $\begin{array}{l}\mathrm{SO}_{2} \\
(\mathrm{ppb})\end{array}$ & $\begin{array}{c}\mathrm{NO}_{x} \\
(\mathrm{ppb})\end{array}$ & $\begin{array}{l}\mathrm{O}_{3} \\
(\mathrm{ppb})\end{array}$ \\
\hline \multirow{2}{*}{ 11 February } & $12: 35$ & 10.9 & $\mathbf{3 5 . 5}$ & 1.39 & 2.60 & 0.54 & 48.9 \\
& $14: 35$ & $\mathbf{5 3 . 6}$ & $\mathbf{2 9 . 8}$ & 1.49 & 1.36 & 1.98 & 49.9 \\
& $20: 35$ & 3.2 & 8.6 & 1.56 & $\mathbf{9 . 8 2}$ & $\mathbf{8 . 8 7}$ & 41.1 \\
24 March & $5: 35$ & 6.1 & 7.3 & 1.66 & 1.93 & $\mathbf{1 4 . 1}$ & 47.2 \\
& $7: 35$ & $\mathbf{2 8 . 0}$ & $\mathbf{1 6 . 5}$ & 1.52 & 1.51 & $\mathbf{2 1 . 0}$ & 47.7 \\
& $9: 35$ & 3.1 & $<2.0$ & 1.54 & 2.10 & $\mathbf{1 3 . 4}$ & 66.3 \\
16 April & $6: 35$ & 7.4 & $<2.0$ & 1.36 & 1.70 & 8.66 & 58.8 \\
& $10: 35$ & $\mathbf{5 4 . 8}$ & $<2.0$ & 1.33 & $\mathbf{1 1 . 2}$ & $\mathbf{1 5 . 8}$ & 74.6 \\
& $14: 35$ & 13.3 & $<2.0$ & 1.16 & 2.13 & 7.74 & 80.1 \\
17 April & $02: 35$ & 14.3 & $<2.0$ & 1.17 & 2.42 & $\mathbf{1 4 . 8}$ & 60.2 \\
& $6: 35$ & $\mathbf{3 8 . 4}$ & $\mathbf{5 . 6}$ & 1.25 & 2.51 & $\mathbf{7 . 1 1}$ & 69.9 \\
& $10: 35$ & 8.0 & $<2.0$ & 1.35 & 2.07 & 5.45 & 66.7 \\
18 April & $18: 35$ & $\mathbf{2 7 . 2}$ & $<2.0$ & 1.28 & $\mathbf{4 . 0 9}$ & $\mathbf{1 3 . 0}$ & 79.6 \\
& $20: 35$ & $\mathbf{5 3 . 0}$ & $<2.0$ & 1.28 & $\mathbf{4 . 0 4}$ & $\mathbf{1 2 . 0}$ & 84.1 \\
7 May & $17: 35$ & 7.6 & $\mathbf{1 0 . 2}$ & 1.31 & 1.39 & 4.70 & 62.0 \\
& $19: 35$ & $\mathbf{2 6 . 6}$ & 5.7 & 1.24 & $\mathbf{3 . 3 3}$ & 4.73 & 65.8 \\
16 August & $10: 35$ & 8.1 & $<2.0$ & 1.53 & 1.90 & 2.21 & 77.9 \\
& $12: 35$ & $\mathbf{2 1 . 9}$ & $<2.0$ & 1.38 & $\mathbf{7 . 1 3}$ & $\mathbf{5 . 8 2}$ & 86.7 \\
& $14: 35$ & $\mathbf{3 3 . 4}$ & $<2.0$ & 1.38 & $\mathbf{4 . 9 1}$ & 2.78 & 85.1 \\
\hline
\end{tabular}

a $\mathrm{RGM}$ and $\mathrm{HgPM}_{2.5}$ collected on 2-h intervals. $\mathrm{Hg}^{\circ}$ and ancillary gas data collected on 5-min intervals; results for these show the 5-min interval corresponding to RGM and $\mathrm{HgPM}_{2.5}$ collection.

b Results average values for 12:30 and 12:40, and for 16:30 and 16:40, respectively. 
Ancillary Gases, Cape Cod, Apr-July 2008
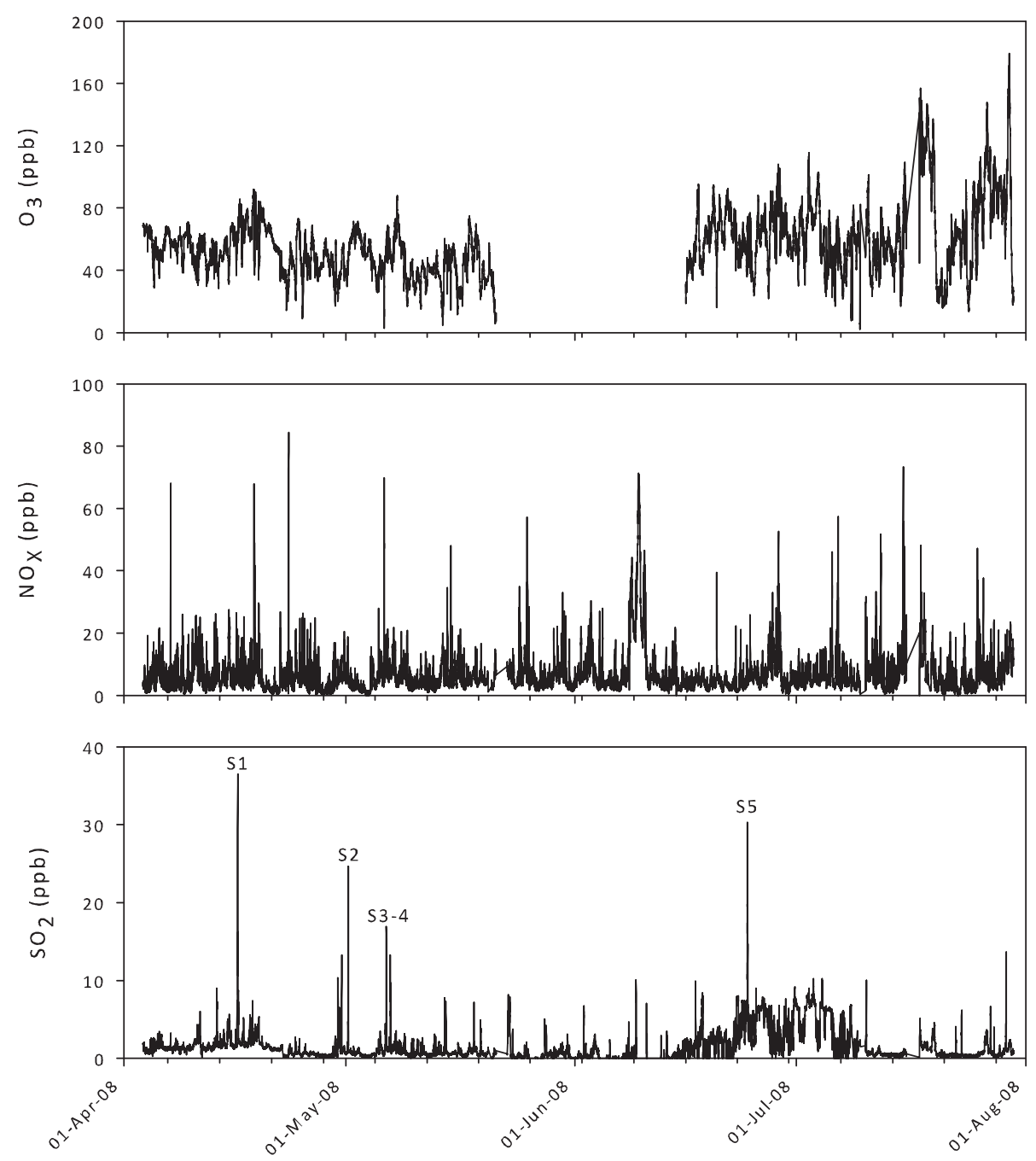

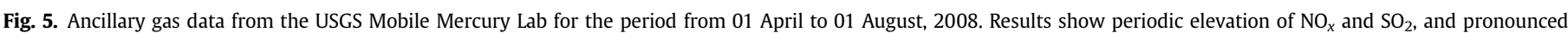

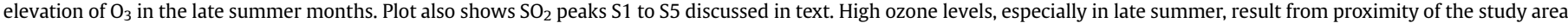
to northeastern urban centers.

$\mathrm{Pb}, \mathrm{Sb}, \mathrm{V}$, and $\mathrm{Zn}$ ) is largely incorporated in air masses coming from the industrial Ohio River Valley and Northeast urban corridor of the United States (Fig. 6b). Some V (and Ni) may be also be contributed more locally by oil-burning power stations, three of which are located within $100 \mathrm{~km}$ of the WHOI site (Engle et al., 2011). In contrast, air masses bearing the marine-factor (containing $\mathrm{Na}, \mathrm{K}, \mathrm{Sr}$, $\mathrm{Mg}$ and $\mathrm{Ca}$ ) are sourced from along the coast, coming from the north, south and Canada's Hudson Bay (Fig. 6c). For the crustal source factor(containing $\mathrm{Al}, \mathrm{Ti}, \mathrm{Y}$ and $\mathrm{Ce}$ ), some air-mass back trajectories originate from the North American interior, but many come from offshore to the east and southeast, where there are no nearby crustal sources (Fig. 6d). These trajectories suggest long range transport of crustal material (following section).

\section{Discussion}

CWT back trajectories for the smelter and energy components are consistent with the distribution of known sources in southern Canada and the U.S. Ohio and Tennessee valleys, respectively. The Ohio valley has the greatest concentration of coal-fired utility power stations in the U.S. and back trajectories show that these airsheds are sampled by prevailing westerly air masses. For the marine component, trajectories show air-mass transport along the Atlantic coast as expected. At first examination, CWT back trajectories for the crustal component are surprising because they parallel those shown by the marine source (Fig. 6). Offshore back trajectories for the crustal component are difficult to explain without long-range transport of crustally derived material. The CWT back trajectories found for the crustal source are consistent with input of African dust transported across the Atlantic from the Saharan region. The transport direction is seasonally variable, with the prevailing seasonal wind direction in the summer months having a westnorthwesterly orientation resulting in maximum dust deposition in regions along the path of the Saharan dust plume such as Florida (Moulin et al., 1997; Riemer et al., 2006; Doherty et al., 2008; Prospero et al., 2010; Trapp et al., 2010; Engelbrecht and Derbyshire, 2010). Arrival of Saharan dust in the eastern U.S. northward into New England has been noted in previous work (Perry et al., 1997) and is explained by clockwise circulation around the Bermuda High, a persistent summer high pressure condition off the coast of Florida.

Mercury speciation and ancillary gas data provide evidence for other processes contributing to aerosol chemistry at WHOI. Amos et al. (2012) showed that oxidized ambient mercury ( $\mathrm{Hg}(\mathrm{II})$ ) 
rapidly partitions between the gas phase (RGM) and particle-bound mercury that includes $\mathrm{HgPM}_{2.5}$. This partitioning is temperature dependent, favoring the gas phase under warm conditions, especially if aerosol contents are low, and the particle phase under cold conditions, especially if aerosol contents are high (Amos et al.,

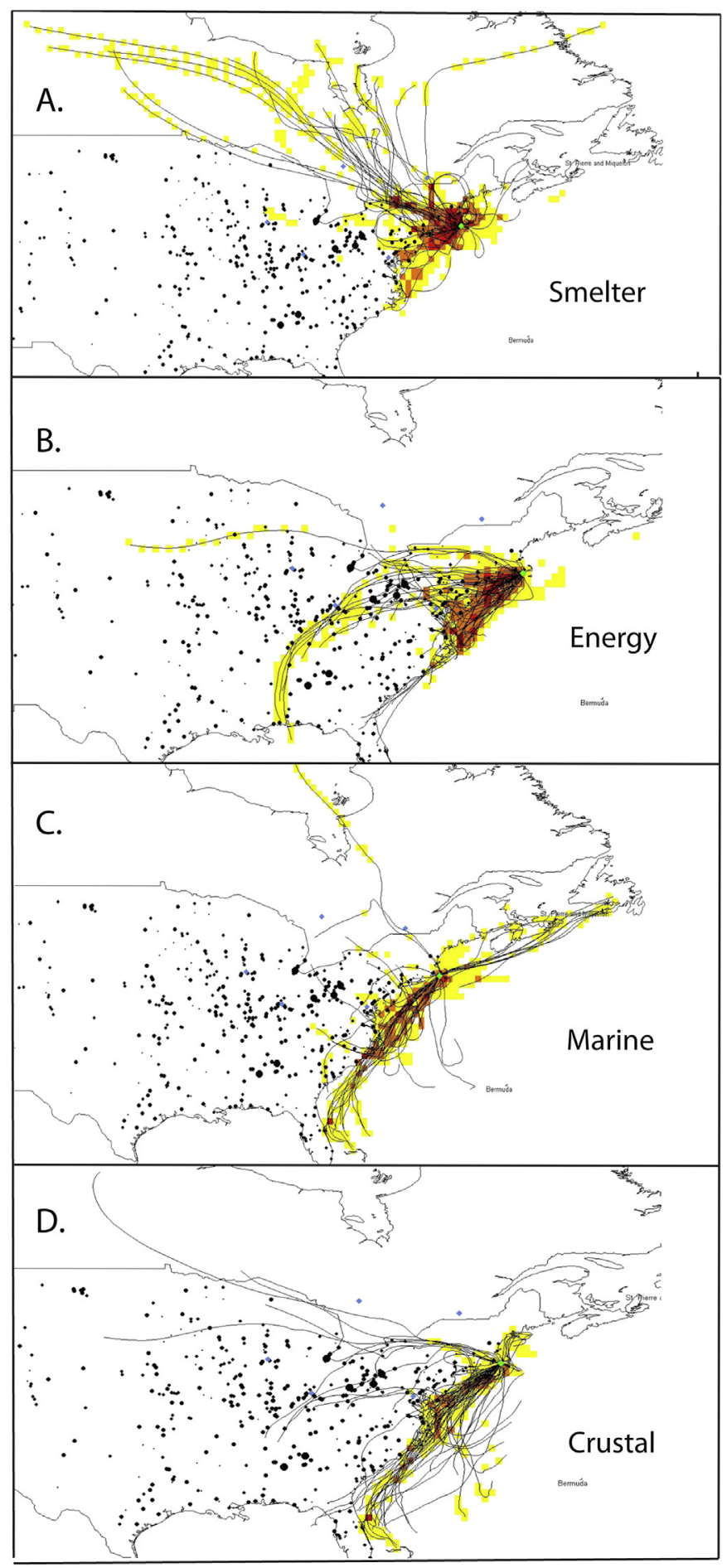

Fig. 6. Regional maps showing the location of the WHOI study site (green dot) together with concentrated-weighted trajectories (CWT) for the uppermost $10 \%$ contribution periods for each factor. For reference, $\mathrm{SO}_{2}$ emitters are also plotted (black dots) scaled to emission load. Warmer colors indicate a greater potential that an air mass originating from that cell contributed a larger fraction of $\mathrm{PM}_{2.5}$ mass and components of the given factor.
2012). In the present study, correspondence of 2-h RGM and $\mathrm{HgPM}_{2.5}$ maxima, at a range of temperatures, suggests that gasparticle partitioning in the $\mathrm{Hg}(\mathrm{II})$ system reaches equilibrium rapidly, but because a large proportion of $\mathrm{HgPM}_{2.5}$ values are below detection $\left(81 \%\right.$ below $\left.2.0 \mathrm{pg} \mathrm{m}^{-3}\right)$, it is not possible to investigate $\mathrm{RGM}-\mathrm{HgPM}_{2.5}$ partitioning in greater detail with this dataset.

Paired $\mathrm{RGM}-\mathrm{SO}_{2}\left(\mathrm{NO}_{x}\right)$ peaks observed at the WHOI site are indicative of transient emission plumes from coal combustion sources (Edgerton et al., 2006; Kolker et al., 2008, 2010). In these cases, $\mathrm{RGM}$ and $\mathrm{SO}_{2}$ concentrations peak over a few hours and fall off rapidly as the plume passes. Evidence for short-term influence of coal combustion at the WHOI site is consistent with PMF modeling indicating energy sources as the major category contributing to $\mathrm{PM}_{2.5}$ formation in the study area over a period of months. As shown by Engle et al. (2010a), in the absence of combustion-related plumes, RGM at the WHOI site shows a diurnal cycle of elevation at mid-day, followed by decrease in the evening and overnight hours. A similar diurnal cycle of RGM variation is found at marine-influenced sites in general (Holmes et al., 2009; Laurier and Mason, 2007) and at eastern U.S. coastal sites ranging from southern New Hampshire (Mao and Talbot, 2012; Sigler et al., 2009a), the Chesapeake Bay (Laurier and Mason, 2007), and the U.S. Gulf Coast (Engle et al., 2008, 2010a). Daily production of RGM occurs by photochemical oxidation of $\mathrm{Hg}^{\circ}$, likely enhanced by the presence of halogens, relative to non-marine settings, and is correlated with diurnal trends in temperature and incident solar radiation (Laurier and Mason, 2007; Engle et al., 2008; Sigler et al., 2009a,b). Engle et al. (2010a) compared patterns of mercury speciation among nine study sites primarily in central and eastern North America, including three coastal sites in the eastern U.S. each having a full year of speciation results: WHOI $\left(41.5^{\circ} \mathrm{N}\right)$, Cape Romain, South Carolina (33.0 $\mathrm{N}$ ), and Weeks Bay, Alabama (30.4 N). Diel bin plots (Engle et al., 2010a, Fig. 3) show that the daily pattern of RGM production is much less pronounced at the WHOI site than at the two more southerly U.S. coastal sites where mean sea surface temperature is higher and photochemical oxidation is greater. These results suggest that RGM production and availability are lesser in the more northerly coastal sites, and this, together with the temperature dependence of $\mathrm{RGM}-\mathrm{HgPM}_{2.5}$ partitioning, may help explain the pronounced differences in mercury deposition found for coastal New England relative to the U.S. Gulf Coast (National Atmospheric Deposition Program, Mercury Deposition Network, 2012).

\section{Summary and conclusions}

Positive matrix factorization was used together with concentration weighted air-mass back trajectories to identify source factors contributing to variation in $\mathrm{PM}_{2.5}$ mass, and the geographic distribution of these sources, in relation to the WHOI site. Factors identified in PMF analysis include energy sources, marine, crustal, and metal smelting components, listed in decreasing order of influence, with the energy factor accounting for more than $40 \%$ of $\mathrm{PM}_{2.5}$ mass. For the energy and metal smelting factors, back trajectories for each factor are consistent with sampling coal-fired power stations concentrated in the U.S. Ohio and Tennessee Valleys, and metal smelting in eastern Canada, respectively. The marine and crustal sources show surprisingly similar back trajectories, at times each sampling Atlantic coastal airsheds. Contribution of crustal material from offshore is explained by the summer trajectory of Saharan dust, leading to a maximum at the latitude of Florida in the summer months, combined with transport northward along the Atlantic Coast by clockwise circulation of the summer Bermuda High. Results for mercury speciation show diurnal RGM maxima from photochemical oxidation of $\mathrm{Hg}^{\circ}$. 
Magnitudes of diurnal RGM production are similar to those observed at two nearby coastal sites in New England and considerably smaller than at southeastern U.S. coastal sites, such as along the Gulf Coast. In addition to diurnal variation, pronounced RGM peaks that rapidly dissipate are correlated with $\mathrm{SO}_{2}$ and $\mathrm{NO}_{x}$ maxima, indicative of plumes from coal combustion sources traversing the WHOI study site.

\section{Acknowledgments}

We acknowledge support of the USGS Toxic Substances Hydrology Program, the USGS Energy Resources Program, the National Science Foundation Small Grants for Exploratory Research Program, and for initial support, the USGS Mendenhall Postdoctoral Program. We thank Woods Hole Oceanographic Institution for providing logistical support for the USGS Mobile Mercury Lab at the Quissett Campus site. Michael Casso (USGS Woods Hole Science Center) and Mark Olson (USGS Wisconsin Water Science Center) assisted in operation of the Mobile Lab. Paul Lamothe (USGS Central Mineral and Environmental Resources Science Center) provided sample analyses.

\section{References}

Amos, H.M., Jacob, D.J., Holmes, C.D., Fisher, J.A., Wang, Q., Corbitt, E.S., Galarneau, E., Rutter, A.P., Gustin, M.S., Steffen, A., Shauer, J.J., Graydon, J.A., St. Louis, V.L., Talbot, R.W., Edgerton, E.S., Zhang, Y., Sunderland, E.M., 2012. Gasparticle partitioning of atmospheric $\mathrm{Hg}$ (II) and its effect on global mercury deposition. Atmospheric Chemistry and Physics 12, 591-603.

Briggs, P.H., Meier, A.L., 2002. The determination of forty-two elements in geological materials by inductively-coupled plasma - mass spectrometry. In: Taggart, J.E.J. (Ed.), Analytical Methods for Chemical Analysis of Geologic and Other Materials. U.S. Geological Survey, pp. 1-14. U.S. Geological Survey Open File Report 02223.

Cooper, O.R., Gao, R.-S., Tarasick, D., Leblanc, T., Sweeney, C., 2012. Long-term ozone trends at rural ozone monitoring sites across the United States, 1990-2010. Journal of Geophysical Research 117, D22307 doi:1029/2012/JD018261.

Doherty, O.M., Riemer, N., Hameed, S., 2008. Saharan mineral dust transport into the Caribbean: observed atmospheric controls and trends. Journal of Geophysical Research 113, D07211 doi:1029/2007/JD009171.

Duce, R., Hoffman, G., Zoller, W., 1975. Atmospheric trace metals at remote northern and southern hemisphere sites: pollution or natural? Science 187 (4171), 59-61.

Edgerton, E.S., Hartsell, B.E., Jansen, J.J., 2006. Mercury speciation in coal-fired power plant plumes observed at three surface sites in the southeastern U.S. Environmental Science and Technology 40, 4563-4570.

Engelbrecht, J.P., Derbyshire, E., 2010. Airborne mineral dust. Elements 6, 241-246.

Engle, M.A., Tate, M.T., Krabbenhoft, D.P., Kolker, Allan, Olson, M.L., Edgerton, E.S. DeWild, J.F., McPherson, A.K., 2008. Characterization and cycling of atmospheric mercury along the central U.S. Gulf Coast. Applied Geochemistry 23 (3), 419437.

Engle, M.A., Tate, M., Krabbenhoft, D.P., Olson, M., Schauer, J.J., Kolker, A., Shanley, J., Bothner, M.H., 2010a. Comparison of mercury speciation and deposition at nine sites across Central and Eastern North America. Journal of Geophysical Research, Atmospheres (D18306), 13.

Engle, Mark A., Krabbenhoft, David P., Sabin, Thomas G., Geboy, Nicholas J., Kolker, Allan, 2010b. Solubility of particulate mercury in coastal waters of the central U.S. Gulf Coast. Abstract A31B-0049, presented at 2010 American Geophysical Union Fall Meeting, San Francisco, CA, 13-17 December.

Engle, M.A., Geboy, N.J., Martín-Fernández, J.A., Olea, R.A., Peucker-Ehrenbrink, B., Kolker, A., Krabbenhoft, D.P., Lamothe, P.J., Bothner, M.H., Tate, M.T., 2011. Source apportionment of atmospheric trace gases and particulate matter: comparison of log-ratio and traditional approaches. In: Proceedings, Fourth International Workshop on Compositional Data Analysis (2011), Sant Feliu de Guixols (Girona), Spain, May, 2011, p. 10.

Gao, Y., Nelson, E.D., Field, M.P., Ding, Q., Li, H., Sherrell, R.M., Gigliotti, C.L., Van Ry, D.A., Glenn, T.R., Eisenreich, S.J., 2002. Characterization of atmospheric trace elements on $\mathrm{PM}_{2.5}$ particulate matter over the New York-New Jersey harbor estuary. Atmospheric Environment 36, 1077-1086.

Geboy, Nicholas J., Engel, Mark A., Krabbenhoft, David P., Sabin, Thomas G., Kolker, Allan, 2011. Assessing inputs of particulate mercury to coastal aquatic ecosystems: abstract. In: Tenth International Conference on Mercury as a Global Pollutant, Halifax, Nova Scotia, Canada.

Golomb, D., Ryan, D., Eby, N., Underhill, J., Zemba, S., 1997. Atmospheric deposition of toxics onto Massachusetts Bay- 1. Metals. Atmospheric Environment 31, 1349-1359.

Holmes, C.D., Jacob, D.J., Mason, R.P., Jaffe, D.A., 2009. Sources and deposition of reactive gaseous mercury in the marine atmosphere. Atmospheric Environment 43, 2278-2285.

Kolker, Allan, Engle, M.A., Krabbenhoft, D.P., Olson, M.L., 2007. Investigating Atmospheric Mercury with the USGS Mobile Mercury Laboratory. USGS Fact Sheet FS 2007-3071, p. 4

Kolker, Allan, Engle, M.A., Orem, W.H., Bunnell, J.E., Lerch, H.E., Krabbenhoft, D.P. Olson, M.L., DeWild, J.F., McCord, J.D., 2008. Mercury, trace elements, and organic constituents in atmospheric fine particulate matter, Shenandoah National Park, Virginia, USA: a combined approach to sampling and analysis. Geostandards and Geoanalytical Research 32 (3), 279-293.

Kolker, Allan, Olson, M.L., Krabbenhoft, D.P., Tate, M.T., Engle, M.A., 2010. Patterns of mercury dispersion from local and regional emission sources in rural Central Wisconsin, USA. Atmospheric Chemistry and Physics 10, 4467-4476.

Laurier, F., Mason, R., 2007. Mercury concentration in the coastal and open ocean boundary layer. Journal of Geophysical Research 112 (D06302), 16.

Mao, H., Talbot, R., 2012. Speciated mercury at marine, coastal and inland sites in New England- Part 1: temporal variability. Atmospheric Chemistry and Physics 12, 5099-5112.

Mao, H., Talbot, R., Hegarty, J., Koermer, J., 2012. Speciated mercury at marine, coastal and inland sites in New England- Part 2: relationships with atmospheric physical parameters. Atmospheric Chemistry and Physics 12, 4181-4206.

Massachusetts Department of Environmental Protection, 2012. Air Quality and Monitoring. In: Ozone Exceedances. http://www.mass.gov/dep/air/aq/ exceedances.htm (accessed 01.31.13.).

Moulin, C., Lambert, C.E., Dulac, F., Dayan, U., 1997. Control of atmospheric export of dust from North Africa by the North Atlantic Oscillation. Nature 387, 691-694.

National Atmospheric Deposition Program, Mercury Deposition Network, 2012. http://nadp.sws.uiuc.edu/mdn/ (accessed 01.03.12.)

Paatero, P., Tapper, U., 1994. Positive matrix factorization: a non-negative factor model with optimal utilization of error estimates of data values. Environmetrics 5, 111-126.

Pacyna, J.M., Pacyna, E.G., 2001. An assessment of global and regional emissions of trace metals to the atmosphere from anthropogenic sources worldwide. Environmental Reviews 9, 269-298.

Perry, K.D., Cahill, T.A., Eldred, R.A., Dutcher, D.D., 1997. Long-range transport of North African dust to the eastern United States. Journal of Geophysical Research 102 (D10), 11, 225-11, 238.

Prospero, J.M., Landing, W.M., Schultz, M., 2010. African dust deposition to Florida: temporal and spatial variability and comparisons to models. Journal of Geophysical Research 115 (D13304), 19. http://dx.doi.org/10.1029/2009JD012773.

Reff, A., Eberly, S.I., Bhave, P.V., 2007. Receptor modeling of ambient particulate matter data using positive matrix factorization: review of existing methods. Journal of Air and Waste Management Association 57, 146-154.

Riemer, N., Deherty, O.M., Hameed, S., 2006. On the variability of African dust transport across the Atlantic. Journal of Geophysical Research Letters 33 (L13814), 4. http://dx.doi.org/10.1029/2006GL026163.

Sigler, J.M., Mao, H., Talbot, R., 2009a. Gaseous elemental and reactive mercury in Southern New Hampshire. Atmospheric Chemistry and Physics 9, 1929-1942.

Sigler, J.M., Mao, H., Sive, B.C., Talbot, R., 2009b. Oceanic influence on atmospheric mercury at coastal and inland sites: a springtime noreaster in New England. Atmospheric Chemistry and Physics 9, 4023-4030.

Song, X.-H., Polissar, A.V., Hopke, P.K., 2001. Sources of fine particle composition in the northeastern US. Atmospheric Environment 35, 5277-5286.

Trapp, J.M., Millero, F.J., Prospero, J.M., 2010. Temporal variability of the elemental composition of African dust measured in trade wind aerosols at Barbados and Miami. Marine Chemistry 120, 71-82.

U.S. Environmental Protection Agency (EPA), 2012a. Toxics Release Inventory (TRI) http://iaspub.epa.gov/triexplorer/tri_release.chemical (accessed 15.03.12.).

U.S. Environmental Protection Agency (EPA), 2012b. Ground-level Ozone (Smog) Information. EPA, New England. Region 1 http://www.epa.gov/region1/ airquality/index.html (accessed 24.09.12.).

U.S. Environmental Protection Agency (EPA), 2012c. EPA Positive Matrix Factorization (PMF) 3.0 Model. http://www.epa.gov/heasd/products/pmf/pmf.html (accessed 15.03.12.).

Valente, R., Shea, C., Lynn Humes, K., Tanner, R., 2007. Atmospheric mercury in the Great Smoky Mountains compared to regional and global levels. Atmospheric Environment 41 (9), 1861-1873.

Wang, Y.Q., Zhang, X.Y., Draxler, R.R., 2009. TrajStat: GIS-based software that uses various trajectory statistical analysis methods to identify potential sources from long-term air pollution measurement data. Environmental Modelling and Software 24 (8), 938-939. 